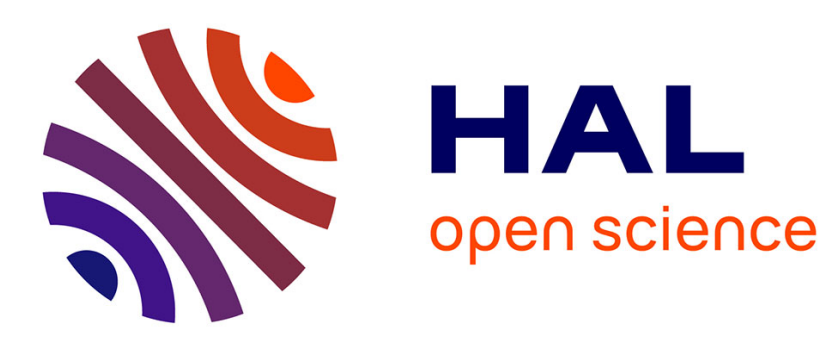

\title{
Qadis and Their Social Networks: Defining the Judge's Neutrality in Abbasid Iraq
}

\author{
Mathieu Tillier
}

\section{To cite this version:}

Mathieu Tillier. Qadis and Their Social Networks: Defining the Judge's Neutrality in Abbasid Iraq. Journal of Abbasid Studies, 2017, 4 (2), pp.123-141. 10.1163/22142371-12340032 . halshs-02308217

\section{HAL Id: halshs-02308217 https://shs.hal.science/halshs-02308217}

Submitted on 8 Oct 2019

HAL is a multi-disciplinary open access archive for the deposit and dissemination of scientific research documents, whether they are published or not. The documents may come from teaching and research institutions in France or abroad, or from public or private research centers.
L'archive ouverte pluridisciplinaire HAL, est destinée au dépôt et à la diffusion de documents scientifiques de niveau recherche, publiés ou non, émanant des établissements d'enseignement et de recherche français ou étrangers, des laboratoires publics ou privés. 


\title{
Qadis and Their Social Networks: Defining the Judge's Neutrality in Abbasid Iraq
}

\author{
Mathieu Tillier \\ Université Paris-Sorbonne, France
}

\begin{abstract}
Early Abbasid qadis were appointed not only to dispense justice but also to manage properties. They needed, therefore, to know the business of their district's population, and their integration into local society facilitated their understanding of social dynamics. However, their membership in local and tribal networks could threaten their judicial neutrality. How could the relations a qadi maintained with his social environment be reconciled with the imperatives of Islamic justice? This article proposes that two types of solutions were experimented with. On the administrative level, qadis designated from outside their judicial district reduced the influence of their family and tribal networks, which led them to rely on new networks, through professional witnesses in particular. At the same time, Islamic legal theory came to discuss a qadi's ability to base his legal judgment on his personal knowledge of a case, which allowed defining a strict separation between a qadi's social individuality and his judicial function.
\end{abstract}

Keywords: Abbasid society; Iraq; Islamic law; judgeship; tribes

\section{INTRODUCTION}

Legal sources regarding the functioning of the Islamic judiciary highlight the social dimension of the qadis' dispensing of justice. One of the earliest theoretical texts on the subject, a letter attributed to the Caliph 'Umar (r. 13-23/634-644), considers the qadi not only a judge but also a mediator whose role was primarily to restore social harmony. Instead of deciding between litigants, he could help them reach an amicable settlement. Inside the courtroom, moreover, social hierarchies were supposed to be abolished. Whatever their religion, social position, or wealth, litigants should be equal before the law. The qadi had to refrain from any show of favor toward any of them and deal with them all in exactly the same way. ${ }^{1}$ In addition to abolishing social hierarchies, institutional hierarchies were also modified. At his hearing, a qadi was regarded as the only master after God. Although he was, administratively, a mere delegate of the sovereign, even the ruler should submit to the qadi's justice if he were to appear before him. This model that Muslim jurists developed gave judges considerable power. ${ }^{2}$

However, this important authority could threaten the absolute neutrality required of a qadi. The judiciary's functioning during the classical period increased this danger. According to procedures that had been implemented since the first/seventh century, the Muslim qadi was a single judge, who passed judgment alone, having sole jurisdiction over a district that usually encompassed an entire city and its hinterland. Because of this isolation, a judge could hardly withdraw (or be impeached) in favor of another judge when confronted with a case whose ramifications affected him personally. This problem was identified by the authors of adab al-

\footnotetext{
${ }^{1}$ Tillier, La société abbasside au miroir du tribunal, 157-160.

2 Tillier, Judicial Authority, 119-131.
} 
$q \bar{a} d \bar{l} \bar{\imath}$ manuals (treatises about judicial procedures and qadis' duties), who address a judge's social relationships and the way he should manage them to preserve his neutrality. In the midtwentieth century, Emile Tyan discussed their recommendations in terms of moral behavior: he showed how qadis' social activities multiplied the risks of corruption. ${ }^{3}$ I would like to reopen this file through another, social and institutional, prism. Relying on legal and biographical sources concerning Abbasid Iraq (second/eighth to fourth/tenth century), I will first argue that qadis could not avoid the surrounding social world in exercising their judicial functions. Second, I will show how their inclusion in social networks made them vulnerable to pressure. Finally, I will focus on administrative and legal solutions that were supposed to minimize their social integration's impact on the course of justice.

\section{A QAdi Must Know the People under his JuRisdiction}

In Iraq during the 750s CE, because of the procedures of the courts, a qadi needed to keep an eye on the urban society in which he dispensed justice. He had to know his district's population for professional purposes. A large part of the judicial process was based on the oral testimony (bayyina) of two honest and trustworthy witnesses. If the qadi was uncertain about the reliability of witnesses testifying at his hearing, he needed to investigate their morality. At the beginning of the Abbasid period, the court's structure was still rudimentary, and there were only few judicial auxiliaries. ${ }^{4}$ The qadi often had to check the witnesses' probity ('adāla) himself. Wakī' describes how Sawwār b. 'Abdallāh al-'Anbarī, qadi of Basra (in office 137/754-5, then 140-156/757-773), went on his mule to the Azd quarter at night with an auxiliary perched on a donkey, knocked at several houses, and asked their inhabitants about a witness. ${ }^{5}$ A few years later, 'Abd al-Raḥmān b. Muhammad al-Makhzūmī did the same. ${ }^{6}$ Being a judge thus meant meeting with the local population in order to assess its members' morality: the legal system's rules of evidence depended on it.

The knowledge that a qadi needed to acquire about his district went beyond issues of legal evidence. Iraqi qadis also exercised municipal administrative functions. Among their main tasks, they had to stand in for adult males who could not manage their personal and family assets - because they were deceased, missing, or legally incapable. As guardian of an orphan girl from Kufa in the late second/eighth century, Hafṣ b. Ghiyāth al-Nakha' $\overline{1}$ (in office 177?194/793-810) ordered an auxiliary to investigate the orthodoxy and morality of a man who wanted to marry her, in order to protect her from the marriage's possible negative consequences. ${ }^{7}$ Qadis also managed absent persons' properties - especially those of travelers — and thus needed to find honest men to safeguard their money. ${ }^{8}$ In the third/ninth century, the Iraqi Ḥanafĩ jurist al-Khașșāf (d. 261/874) recommended that qadis find trustworthy neighbors to provide accommodation to women who accused their husbands of ill-treatment; they would then ask these neighbors about the husband's conduct toward his wife. ${ }^{9}$ In many other cases,

\footnotetext{
3 Tyan, Histoire de l'organisation judiciaire, 290-3.

4 Tillier, L'invention du cadi, 204-212.

${ }^{5}$ Wakī' ${ }^{\circ}$ Akhbār al-quḍāt, II, 83-4.

${ }^{6}$ Ibid., II, 141.

${ }^{7}$ Ibid., III, 185; cf. ibid., III, 188.

${ }^{8}$ See, for example, ibid., III, 134.

${ }^{9}$ Khașșāf, Adab al-qāộ̀, 652.
} 
the qadi had to rely on men "whom he trusted" (yathiqu bihim), ${ }^{10}$ an expression that reveals once again the personal knowledge about his constituency a qadi needed to acquire. Much of his work depended on his ability to collect intelligence about people he did not know personally. In theory, he was thus at the center of a network of righteous people on whom he could rely for help in administering the city.

A qadi should not only know his district's people, but also understand the local society at large. In Iraq, where tribes were still the basic social unit, he had to master genealogies and the composition of lineage groups, so as to properly divide inheritances and rule on legacies. ${ }^{11} \mathrm{In}$ the second half of the second/eighth century, a qadi of Kufa, Sharīk b. 'Abdallāh (in office 153169?/770-786?), had a thorough knowledge of the city's inhabitants. Born in Khurasan or Ferghana, and raised in the Sawād (the hinterland of Kufa), ${ }^{12}$ he knew Aramaic (nabatiyya), which he spoke to some converts during hearings. ${ }^{13}$

The requirement that a qadi learn about his district's population, however, remained largely theoretical. In practice, despite his auxiliaries' help and his social networks, a qadi could still be cheated. In a megalopolis such as late second/eighth-century Baghdad, witnesses who introduced themselves as famous imams of the city fooled Qadi Abū Yūsuf (d. 182/798). The investigations the qadi ordered into their reputation naturally led to their recognition as trustworthy witnesses, until the defendant who had unjustly lost the trial discovered the fraud. ${ }^{14}$ Identifying individuals, whether litigants or witnesses, remained a challenge of which legal theory was fully aware. ${ }^{15}$

A qadi's expertise in the affairs of the local population (the 'a $m m a$ ) was nevertheless recognized by political authorities. This appears especially in the first half of the third/ninth century, when the chief qadi became increasingly important at the caliph's court. ${ }^{16}$ During the fourth fitna (the war between Caliph al-Amīn and his brother al-Ma'mūn, and its aftermath), the governor of Baghdad, al-Hasan b. Sahl, charged a qadi of the capital, Muhammad b. Samā'a, with finding a trustworthy man, using the qadi's Iraqi network. ${ }^{17}$ When al-Ma' mūn (r. 198218/813-833) wished to curse Mu'āwiya from the pulpits of the mosques, the Chief Qadi Yahyā b. Aktham dissuaded him, arguing that the people - especially the Khurasanians - would not agree and might rebel. ${ }^{18}$ Later, the Caliph al-Mutawakkil (r. 232-247/847-861) turned to the same Yahyā b. Aktham for help in understanding the relationship between a merchant named Ibn al-Abzārī and the agitator Aḥmad b. Naṣr al-Khuzā ‘̄i, since Ibn al-Abzārī had organized the funeral of the latter after his execution. ${ }^{19}$ The Chief Qadi Aḥmad b. Abī Du'ād served as an intermediary between the Caliph al-Mu tașim (r. 218-227/833-842) and merchants of the Karkh district in Baghdad after a large fire ruined their businesses in 225/839-40. The qadi asked the

\footnotetext{
${ }^{10}$ See, for example, ibid., 252.

${ }^{11}$ Wakī', Akhbār al-quḍāt, II, 119; see also Tillier, Les cadis d'Iraq et l'État abbasside, 191-4.

${ }^{12} \mathrm{Wak}^{\prime}$ ', Akhbār al-qud̄àt, III, 150-151; see also al-Khațīb al-Baghdādī, Ta'rīkh, X, 385.

${ }^{13} \mathrm{Wakī}^{\mathrm{c}}$, Akhbār al-qud̄àt, III, 167.

${ }^{14}$ Ibid., III, 262.

${ }^{15}$ See Tillier, L'identification en justice, 97-112.

${ }^{16}$ See Tillier, Les cadis d'Iraq, $443 \mathrm{ff}$.

${ }^{17}$ Qālī, Amālì, I, 249; see also Hammāda, Wathā 'iq, 350.

${ }^{18}$ Ibn Tayfūr, Kitāb Baghdād, 54.

${ }^{19}$ Țabarī, Ta 'rìkh, III/3, 1413. On al-Khuzā' $\overline{1}$, see the references provided in Tillier, Les cadis d'Iraq, 569.
} 
caliph in Samarra for financial assistance, and distributed five million dirhams among the disaster victims. ${ }^{20}$

\section{QADIS' SOCIAL NETWORKS}

\section{The issue of social interactions}

Knowing his district's population was part of a qadi's work. However, this knowledge went far beyond a mere professional network. Many allusions to Iraqi qadis' social life and interactions with their neighbors or fellow town residents appear in biographical sources. They participated in collective religious rituals such as the daily and Friday prayers, ${ }^{21}$ and attended funerals. ${ }^{22}$ People came to qadis' homes when a relative had died to offer their condolences. ${ }^{23}$ Qadis visited and received friends, ${ }^{24}$ accompanied acquaintances at meals or festive banquets, ${ }^{25}$ and offered food to neighbors for their sons' birth. ${ }^{26}$ They attended public baths, ${ }^{27}$ and saw dream interpreters. ${ }^{28}$ Sometimes aspects of a qadi's private life could become known to those outside his household, as evidenced by the story about a qadi of Basra, 'Umar b. 'Uthmān alTaymī, during the reign of Hārūn al-Rashīd (r. 170-193/786-809):

'Umar b. 'Uthmān bought a slave girl while he was qadi of Basra. She slept at his home, and in the morning the people (al-nās) came and asked about the night he had spent with her. He replied: "She has two heavenly virtues: she is pleasant and unrestrained!" 29

Due to social interactions, a qadi necessarily entered into symmetrical relationships involving reciprocity. In other words, he contracted material or symbolic debts that became subtle instruments of pressure on his legal activities. Patronage networks were based on exchange of services ( $h \bar{a} j a)$. Most often, sources present qadis as the heads of such networks: people came to them for help, and the qadis provided benefits to those who became their clients. ${ }^{30}$ Sometimes, however, a qadi benefited from someone and became his client. ${ }^{31}$ For example, Qadi 'Abdallāh b. Shubruma asked Abū Ayyūb al-Mūriyān̄̄, Caliph al-Manșūr's (r. 136-158/754-775) personal secretary, to fund his son's wedding. ${ }^{32}$ Later, Qadi al-Wāqidī

\footnotetext{
${ }^{20}$ Tanūkhī, Nishwār al-muhạạdara, II, 101-3; cf. Ibn al-Jawzī, Muntaẓam, VI, 338.

${ }^{21}$ Wakī̄, Akhbār al-quḍāt, II, 79.

${ }^{22}$ Ibid., II, 169-170, 180; Mas 'ūdī, Murūj al-dhahab, V, 208; al-Khațīb al-Baghdādī, Ta 'rìkh, V, 55; Ibn alJawzī, Muntazam, VIII, 104.

${ }^{23}$ Wak̄̄', Akhbār al-quḍāt, II, 47, 124; al-Qāḍ̄i 'Iyāḍ, Tartīb al-madārik, IV, 283-4.

${ }^{24}$ Wakī', Akhbār al-quḍ̄̄t, III, 186; al-Qāḍ̄̄ 'Iyāḍ, Tart̄̄b al-madārik, IV, 283.

${ }^{25}$ Wakī‘, Akhbār al-quḍāt, III, 164.

${ }^{26}$ Ibn Qutayba, 'Uyūn al-akhbār, III, 228.

${ }^{27}$ Al-Khațî̉ al-Baghdādī, Ta'rīkh, X, 292; Ibn al-Jawzī, Muntaẓam, VI, 526.

${ }^{28}$ Ibn al-Jawzī, Muntazam, VII, 324-5.

${ }^{29} \mathrm{Wak}^{`}{ }^{\prime}$, Akhbār al-quḍāt, II, 136.

${ }^{30}$ See, for example, Wakī', Akhbār al-quḍāt, I, 245; II, 114; III, 183, 298; Ibn Khallikān, Wafayāt al-a yān, VI,

37; Ibn Hajar, Raf'al-ișr, 49.

${ }^{31}$ See, for example, Wakī' ${ }^{`}$ Akhbār al-qudāt, III, 94.

${ }^{32}$ Wak̄̄‘, Akhbār al-qud̄àt, III, 118. The text reads erroneously “al-Marzubān̄̄” instead of "al-Mūriyānī.” On this secretary, see Sourdel, Le vizirat' 'abbāside, I, 78-87.
} 
(d. 207/822-3) faced financial difficulties and asked one of his friends to help him buy his children new clothes for one of the two main festivals ( ${ }^{i} \mathrm{i} d$ ) of the Islamic calendar. ${ }^{33}$

The qadis' integration into the social fabric, their familiarity with potential litigants, and the patronage relationships created by their daily interactions, raise the question of their potential personal bias in the courtroom. In Kufa, Qadi al-Qāsim b. Ma'n (in office 169-175/785-792) once heard his herald announce Hamās b. Nāmil, a thief and poet (liṣss). The qadi, clearly an admirer of the poet's literary art, started reciting two of his verses, before he had him sit down and heard his case. ${ }^{34}$ Although Wakī', who narrates his biography, refrains from any comment, the anecdote reveals a Muslim judge's ambiguous position. To what extent could qadis remain impartial when they had to decide the fate of litigants they knew? During the Umayyad period, some qadis were already accused of favoring their friends $(i k h w a \bar{n}) .{ }^{35}$ Biographical accounts relating to the Abbasid era suggest that even the most honest judge's neutrality could easily be eroded.

According to Wakī', a famous qadi of Basra from the time of al-Mahdī (r. 158-169/775785), 'Ubayd Allāh b. al-Ḥasan al- 'Anbarī (d. 168/784-5), was biased (mutaḥāmil) towards a litigant during a trial opposing two local families. The Umayyad Caliph Sulaymān b. 'Abd alMalik (r. 96-99/715-717) had confiscated a rural estate belonging to the Banū 'Abd al-Malik, descendants of a former governor of Iraq, al-Hajjāj b. Yūsuf. They now reclaimed the land from its new owner, Sulaymān b. 'Ubayd Allāh, to whom Caliph al-Saffāḥ (r. 132-136/749-754) had assigned it. The claimants went to the qadi and asked him to "use his cunning" (yahtâl) to give it back to them. The qadi, who knew them and considered them victims of spoliation, agreed to their request. ${ }^{36}$ He probably neither thought he was unjust nor that he departed from his duties. The case was related to the Abbasid caliphate who had granted the land, and was therefore sensitive. Restoring what the qadi believed just and reasonable could justify extraordinary means. Nevertheless, from the outside, this case demonstrates how a qadi could struggle reconciling an ideal of justice with strict law enforcement.

This difficulty caused qadis anxiety, which medieval sources express through an eschatological leitmotif: to avoid compromising his own salvation in the hereafter, ${ }^{37}$ a "good" jurist should not willingly accept the position of a judge, and must rejoice when he is eventually dismissed. Beyond this topos, which also aimed at establishing a judicial system independent from the government, ${ }^{38}$ some qadis could feel real discomfort. 'Abd al-Raḥmān b. Muḥammad al-Makhzūmī, qadi of Basra under Hārūn al-Rashīd, had previously served as legal advisor for a man called Khalaf b. 'Amr. Once he became a judge, he had to rule on his suit! The qadi prayed that he be dismissed before he had to render judgment. ${ }^{39}$ One could not be a defense attorney and a judge in the same lawsuit: any confusion of roles appeared as morally, if not legally, unbearable.

\section{Local qadis and their tribal networks}

\footnotetext{
${ }^{33}$ Ibn Khallikān, Wafayāt al-a yān, IV, 349.

${ }^{34} \mathrm{Wak}_{\overline{1}}{ }^{\prime}$, Akhbār al-qud̄àt, II, 179.

${ }^{35}$ Ibn Qutayba, 'Uyūn al-akhbār, I, 70.

${ }^{36} \mathrm{Wak}^{`}{ }^{\prime}, A k h b \bar{a} r$ al-qud̄àt, II, 93. On this event, see also Tillier, Judicial Authority, 124-5.

${ }^{37}$ See Tillier, The Qā $\bar{l} \bar{l}$ before the Judge, 267.

${ }^{38}$ Tillier, Les cadis d'Iraq, 625-630.

${ }^{39}$ Wakī', Akhbār al-quḍāt, II, 141.
} 
Beyond daily interactions, qadis of the second half of the second/eighth century belonged to tribal networks. Tribes still represented the basic social structure in Iraq. In Basra and Kufa, qadis were recruited from the dominant tribes, which contributed to consolidating their authority in their city. ${ }^{40}$ Most Iraqi qadis were members of the tribal elite and many were labeled by their biographers as, for instance, sharîf, $r a{ }^{\prime} \bar{\imath}$, min al-wujūh/al-nubalāa. ${ }^{41}$ These notables thus benefited from the bonds tribal solidarity created. In Basra, Tamim tribesmen waited at the door of Sawwār b. 'Abdallāh al- 'Anbarī (in office 137/755, then 140-156/757-773) on the morning of the Sacrifice festival to accompany him in procession to the musalla. ${ }^{42}$ People were proud to have a fellow tribesman as judge. ${ }^{43}$ Replying to poets who had denigrated the Basran Qadi Mu'ādh b. Mu'ādh (in office 172/788-9, then 181-191/797-807), Abān b. 'Abd al-Hamīd al-Lāhiqīi (d. ca. 200/815-6) concluded: "Enough disdain, O tribes! You should know that the house of justice is among al- 'Anbar!" 44

Belonging to powerful local tribes strengthened the authority of qadis and gave their decisions binding force. One of the most striking examples of this phenomenon is the conflict in Basra between Qadi Sawwār b. 'Abdallāh and the police chief 'Uqba b. Salm al-Hunā'ì. The latter had wrongly imprisoned a man, whose wife then complained to the qadi. As the police chief refused to release the man, Sawwār threatened to come and kill him with his bare hands. The police chief's advisors encouraged him to relent, arguing that

this is the qadi of the Commander of the Faithful! He belongs to Tamīm, Muḍar, and Bal'anbar [Banū l-'Anbar], and all members of these tribes are willing to take up arms for him! As for you, you belong to Yaman, and no major figure in Basra belongs to them. ${ }^{45}$

In an Islamic world where qadis were still struggling to establish themselves as the supreme judicial authorities, tribal solidarities remained an essential instrument of power.

A qadi's tribe was also his weakness, for it exposed him to both internal and external pressures. According to Ibn Sa 'd, Sharīk b. 'Abdallāh wanted to decline the judicial position that Caliph al-Manșūr had offered him. To prevent him from running away, the latter threatened to harm fifty members of his tribe (qawm) if he were to disappear. ${ }^{46}$ Several qadis were also suspected of tribal bias. In Basra, a Yamanī litigant accused 'Ubayd Allāh b. al-Ḥasan al'Anbarī of having ill-treated him due to the qadi's affiliation with a Mudarī tribe. During the discussion that ensued, the qadi disparaged many Yamanī clans. ${ }^{47}$ Tribal tensions were still alive, and the same qadi did not always refrain from provoking litigants. ${ }^{48}$

\footnotetext{
40 Tillier, Les cadis d'Iraq, 196-198, 203-210.

${ }^{41}$ See, for example, Wakī', Akhbār al-quḍāt, II, 50, 88, 131; III, 180, 297; Ibn Khallikān, Wafayāt al-a yāan, VI, 147, 382; Ibn Ab̄̄ l-Wafā', Jawāhir, I, 148, 412; Sam 'ānī, Ansāb, V, 336; Ibn Ḥajar, Raf' al-iṣr, 390; cf. Ibn Qutayba, Ma'ārif, 520.

${ }^{42}$ Wak̄̄', Akhbār al-qudāt, II, 84.

${ }^{43}$ See, for example, Ibn Khallikān, Wafayāt al-a yān, I, 86; Ibn Hajar, Raf' al-iṣr, 52.

${ }^{44}$ Wakī', Akhbār al-qudāt, II, 153. On this poet, see Stern, Abān b. 'Abd al-Hamīd.

${ }^{45}$ Wakī', Akhbār al-quḍāt, II, 59.

${ }^{46} \mathrm{Ibn}$ Sa'd, Tabaqāt, VI, 379.

${ }^{47} \mathrm{Wak}^{\circ}{ }^{`}$, Akhbār al-quḍāt, II, 109-110.

${ }^{48}$ Ibid., II, 114.
} 
Some evidence also suggests that qadis relied on their tribal networks while in office. In Kufa, Sharīk b. 'Abdallāh employed a member of his own tribe, Nakha', as an auxiliary. ${ }^{49}$ Qadi Hafs b. Ghiyāth al-Nakha' $\overline{1}$ is described as listening to the advice of someone who bore the same tribal nisba as himself. ${ }^{50}$ A qadi's tribe could derive material benefits from his official position. Hafṣ b. Ghiyāth generously donated the bonus Caliph Hārūn al-Rashīd gave him to his "brothers" (ikhwān). ${ }^{51}$ He offered money to Yahyā b. Ādam's mother, who came to greet him before leaving for Mecca, so that she could "help the elders of the tribe (hayy) to perform the pilgrimage." ${ }^{, 52}$ A qadi's arrival in office awakened the cupidity of his tribal circle, as we can see in a poem composed by Abān b. 'Abd al-Ḥamīd, when Mu'ādh b. Mu'ādh came back as Basra's judge in Rajab 181/September 797:

The tribesmen of Lāhiq and sons of Tamīm are ready:

They rolled up their robes and coated the place of prayer with garlic.

Behold how they no longer leave the mosque, after neglecting it!

For you, [Mu'ādh], some are now fasting who had never done so:

Like the wolf watching the first rays of dawn in the dark night,

They all hope he will entrust them with an orphan's money! ${ }^{53}$

This aging qadi of the Banū 1-'Anbar tribe, a branch of Tamīm, attracted greedy and unscrupulous people, for whom managing properties was a source of wealth. As suggested by the poet, $\mathrm{Mu}$ 'ādh was expected to recruit property managers from his tribal circle - in which religious hypocrites consequently multiplied, hoping that the qadi would consider them to be trustworthy men. Indeed, the qadi was rapidly dominated by a group of greedy men ( hhurra $\left.\bar{a}^{\prime}\right)$ belonging to Tamīmī clans and others related or allied to that same tribe (Numayr, Țafāwa, Bāhila), ${ }^{54}$ who spoke in his place in the courtroom. ${ }^{55}$ A Bedouin woman depicted such profiteers as wolves when she blamed the qadi for letting two predators dictate his decisions. ${ }^{56} \mathrm{~A}$ delegation of Basran inhabitants even travelled to Baghdad to complain about their qadi. ${ }^{57}$ It may therefore be no coincidence that the next qadi, Muḥammad b. 'Abdallāh al-Anșāiñ (in office 198-202/813-818), was selected from the Anșar, a "detribalized” group primarily characterized by its Medinese ancestors' religious virtues. The new judge hastened to distance himself from his predecessor's nepotistic policies, and handed back to the orphans the properties $\mathrm{Mu}^{\prime} \mathrm{a} \mathrm{dh}$ had entrusted to dishonest administrators. ${ }^{58}$

Qadis' difficulty in distancing themselves from their tribal networks could even extend to the courtroom. Someone called Salama b. 'Ayyāsh, who litigated against a mawlā of the Basran qadi Khālid b. Țalīq (in office 166-167?/782-784?) feared the latter’s bias. Despite the flattering

\footnotetext{
${ }^{49}$ Ibid., III, 165.

${ }^{50}$ Ibid., III, 187.

51 Ibid., III, 185.

${ }^{52}$ Ibid., III, 185. On his father's side, Yahyā b. Ādam (d. 203/818) was a mawlā of Quraysh (Schmucker, Yahyā

b. Ādām). Wakī'ss report suggests that his mother belonged, as did the qadi, to al-Nakha' tribe.

${ }^{53} \mathrm{Wakī}^{\prime}$, Akhbār al-quẹ̄at, II, 147.

${ }^{54}$ Numayr is the name of one of Tamīm's clans (Levi della Vida, Numayr.); on Ṭafāwa, a Muḍarī tribe like

Tamīm, see Ibn Hazm, Jamharat, II, 480.

${ }^{55}$ Wakī', Akhbār al-qud̄āt, II, 148.

${ }^{56}$ Ibid., II, 148.

${ }^{57}$ See Tillier, Les cadis d'Iraq, 246.

${ }^{58} \mathrm{Wakī}^{\prime}$, Akhbār al-qudāt, II, 154.
} 
verses he sent him - in which he praised the qadi's strictness with his own relatives - Salama lost the case. ${ }^{59}$ Conversely, Qadi 'Ubayd Allāh b. al-Hasan al-'Anbarī had to pass judgment against a fellow tribesman, who had probably failed to produce witnesses, and who responded angrily to what he considered an unfair decision. ${ }^{60}$ Indeed, a qadi's fellow tribesmen expected him to defend their interests, even by contravening the rules of procedure. An ideal qadi, as pictured by later authors, managed to escape the pressure exerted by his (tribal) circle, who hoped to take advantage of his position. Al-Jāhiz finds this ideal in the qadi of Basra, 'Abdallāh b. Sawwār (in office 192-198/807-814): he frightened his "companions," al-Jāhị says, and could not be accused of favoring them. ${ }^{61}$ This qadi met this standard by adopting a rare ascetic rigor, which he expressed by his absolute impassivity in the courtroom and his ability to ignore anything that might distract him. ${ }^{62}$

\section{Administrative ANd Legal Solutions}

\section{An administrative solution: Sending foreign qadis}

The potential influence of social networks on qadis' judicial practice was particularly high during the early Abbasid period, when most were recruited from among local scholars. Whereas the central government usually sent city governors, local elites could reinforce their control of local affairs through the qadi. People also wanted their judiciary to comply with local specificities of Islamic law, and recruiting local qadis was the only way to meet their expectations. ${ }^{63}$

During most of the third/ninth century, Abbasid caliphs still selected qadis of major Iraqi cities from among their inhabitants. In Egypt, however, from the late second/eighth century onwards, more and more judges were sent from outside. ${ }^{64}$ Cutting off the judiciary from local networks was probably not this reform's main purpose. The central government primarily sought to strengthen its authority over distant provinces, and to disseminate legal doctrines that suited its policy. This reform nevertheless reduced the influence of qadis' social networks. The first "foreign" judges sent to Egypt still belonged to Yaman, the dominant tribal confederation of Fustāt, but their longstanding interactions with local people no longer determined their judicial practice.

This reform created new problems, however: qadis sent from another province did not know the people they had to manage. They ignored, in particular, the witnesses' reliability. Each qadi had therefore to rebuild networks to understand Egyptian society. On arriving in Egypt in 185/801, Qadi al-'Umarī asked several renowned jurists to refer him to "a group of local inhabitants" on whom he could rely. ${ }^{65}$ Al-Hasan b. Mūsā al-Ashyab had to do the same when he arrived in Ḥimṣ (Syria). ${ }^{66}$ Ibrāhīm b. al-Jarrāḥ (in office in Fusțāṭ 205-211/820-826) followed

\footnotetext{
${ }^{59}$ Ibid., II, 125-6.

${ }^{60}$ Ișfahān̄i, Aghān̄ì, II, 35.

${ }^{61}$ Jāhịiz, Hayawān, III, 346.

${ }^{62}$ Ibid., III, 343-5.

${ }^{63}$ See Tillier, Legal Knowledge, 197.

${ }^{64}$ Ibid., 201.

${ }^{65}$ Ibn Hajar, Raf' al-iṣr, 221.

${ }^{66}$ Al-Khațīb al-Baghdādī, Ta 'rīkh, VIII, 457.
} 
his son's advice to entrust investigations regarding witnesses to "a local man." ${ }^{67}$ Before his arrival in Fusțāt, in 246/860, the Iraqi Bakkār b. Qutayba inquired about trustworthy people that could help counterbalance his own ignorance of local affairs. ${ }^{68}$ This initial weakness of a foreign qadi, isolated from local networks, probably caused one of the most important reforms to Islamic judgeship, namely the professionalization of testimony. Newcomers could not know the reliability of all the witnesses who came to court. Therefore, they hired teams of witnesses that their successors could take over when they assumed office, and Muslims henceforth made these witnesses the primary means for certifying their legal transactions. ${ }^{69}$

The makeup of these administrative networks, which consisted of notary-witnesses, thus compensated for foreign qadis' deficiencies in regard to local connections. Social pressure on holders of judicial office did not disappear, however, but rather evolved. Its main actors were now networks of professional witnesses, surrounding the judge, who could become very powerful, as in Ikhshīdid Egypt. ${ }^{70}$ Moreover, not every Abbasid province experienced a similar evolution. In Iraq, for about a century, qadis remained recruited from local elites, which delayed the emergence of professional witnesses. ${ }^{71}$ Therefore, it was necessary to find other solutions to reduce a qadi's vulnerability to social pressure. The main response to this issue was to be a legal one.

\section{A legal solution: Distinguishing between a man and his official position}

Jurists were soon aware of the consequences of a qadi's daily interactions with his district's people. Al-Shāfi 'i (d. 204/820) recommended that a qadi (as well as a governor) employ an intermediary to conduct his personal business. No one needed to know whom he was working for, so sellers and buyers could not modulate their prices to endear themselves to the qadi. ${ }^{72}$ The qadi, al-Shāfi 'î argues, may keep a social life and accept invitations. However, he must be careful not to choose his public appearances selectively: he cannot accept some invitations and reject others, but "must accept all or reject all." He may also visit sick people, attend funerals, or accommodate travelers. ${ }^{73}$ A few decades later, the Hanafĩ Iraqi scholar al-Khașșāf qualified these principles. According to him, a qadi should only accept collective invitations ('āmma), that is when other people are also invited. The only individual invitations (khāssa) he may accept are those from his close relatives (qarāba), provided that they were not involved in a lawsuit. ${ }^{74}$ A century later, al-Jașșās added that individual invitations are a form of corruption (rashwa) ${ }^{75}$ Similarly, a qadi must be careful not to let a litigant enter his house without his legal adversary. ${ }^{76}$ The Shāfí ${ }^{1}$ jurist Ibn al-Qāṣs (d. 335/946) for his part insisted that a qadi should not pass judgment on his own family members:

\footnotetext{
${ }^{67}$ Kindī, Akhbār quḍ̄at Miṣr, 428.

${ }^{68}$ Ibn Hajar, Raf' al-iṣr, 100 (transl. Tillier, Vies des cadis, 56).

${ }^{69}$ Tillier, Les “premiers" cadis de Fusțāt, 236.

70 Tillier, The Qāḍ̄is of Fusțāt-Mișr, 217-218.

71 Tillier, Les “premiers" cadis de Fusțāt, 234.

${ }^{72}$ Shāfi '⿳亠丷, Umm, VII, 506.

${ }^{73}$ Ibid., VII, 506.

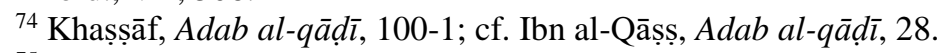

${ }^{75}$ Al-Jașșāṣ, in Khașṣāf, Adab al-qāộ̄, 101.

${ }^{76}$ Khașșāi, Adab al-qā ḍ̂̄ 125.
} 
He cannot dispense justice on a case in which he is involved, nor pass judgment in favor of his slave, his emancipated slave (mudabbar), the slave-girl who bore his son (umm walad), his slave who is given a contract of emancipation (mukatab), or in favor of his partner if the case relates to their partnership..$^{77}$

Finally, Ibn al-Qāṣṣ asserted that someone who expresses too much solidarity with his tribe (muta 'așsib li-qabillatihi) should never be appointed qadi. ${ }^{78}$

In practice, however, limiting interactions between a qadi and his people remained problematic. Even if he was careful not to accept invitations from litigants, a qadi could not renounce all his personal relationships. Moreover, long-term interactions of all kinds could affect judicial practice, not just casual invitations. Most qadis took office at a late age, when they had long been caught up in social relationships they could not unravel. Other legal principles were therefore needed to guarantee their neutrality.

From the second half of the second/eighth century onward, jurists focused on the issue of a qadi's personal knowledge ( 'ilm al-qāậ). If he knew, personally, which of two litigants was right, could he then build on that knowledge to render judgment without any other form of evidence? Many clues suggest that during the Umayyad period, a qadi's personal knowledge was regarded as evidence. ${ }^{79}$ Under Hārūn al-Rashīd, the qadi of Basra, 'Umar b. Habīb, still relied on his own knowledge of a case. When the Barmakī vizier Yahyā b. Khālid bought lands consisting of coastal salt flats in southern Iraq from the Caliph, he sent a representative named al-Qașabī, who soon claimed for his master the ownership of nearly half of the private lands in the area. He produced witnesses who testified that he was the vizier's official representative, and the qadi accepted their testimony. During al-Qașabî's trial against the inhabitants of Basra, however, 'Umar b. Habīb rejected the testimony of the same witnesses and only accepted those who testified in favor of the vizier's adversaries. In theory, since he had recognized al-Qașabī's witnesses as trustworthy the first time, he could not later reject their testimony and should have judged accordingly. As the furious vizier reproached him for his misconduct, 'Umar b. Habīb replied that he knew ('alima) that these witnesses' testimony was unfounded, because it did not correspond to the facts of the case. ${ }^{80}$

On this occasion, the qadi's use of his personal knowledge seems to have served justice: he could end the government's fraudulent land appropriation. Other qadis did not hesitate to condemn someone on the basis of their own experience. After he left the courtroom in Kufa, Ibn Abī Laylā (in office 121-129/739-747, then 132-148/749-766) heard a woman calling a man in the street "son of two adulterers," an insult legally regarded as a slanderous accusation of fornication (qadhf). He had her arrested and brought to the mosque, where he sentenced her to twice the number of lashes prescribed for such a crime ( hadd). ${ }^{81}$

However, as we have seen, such knowledge could also serve private interests, contrary to any sense of justice, and lead to arbitrary judgments. Some would rather rely on rigorous

\footnotetext{
${ }^{77}$ Ibn al-Qāṣṣ, Adab al-qāộ̄, 33.

${ }^{78}$ Ibid., 25.

${ }^{79}$ Tillier, L'invention du cadi, 354-358.

${ }^{80} \mathrm{Wakī}^{`}$, Akhbār al-qud̄àt, II, 143-4.

${ }^{81}$ Ibn Khallikān, Wafayāt al-a yàn, IV, 180. This report contradicts the opinion attributed to Ibn Abī Laylā, holding that a qadi can rely only on the knowledge he acquired at the hearing, and is only a witness of what he learnt outside. Ibn al-Qāṣṣ, Adab al-qā ḍ̄, 39.
} 
procedures, and did not trust what they thought they knew or saw. Sawwār b. 'Abdallāh al'Anbarī (in office in Basra 137/755, then 140-156/757-773) is famous for abstaining from any intervention in people's lives without a judicial accusation. Once, he let a drunk man who had approached him go free, and he refused to intervene when he witnessed in the street what looked like a rape - or at least a case of fornication. Appearances can be misleading, he argued. ${ }^{82}$ Could a judge base his decisions on his daily experience? Did he really know what he thought he knew?

Muslim jurists never agreed on an unequivocal answer. A qadi's knowledge could not be deemed inadmissible in every instance. If testimony proved that one man had murdered another, whereas the qadi knew that the alleged victim was still alive, he could not convict the defendant. Likewise, he should not accept the testimony of men legally regarded as honorable if he knew they were not so in fact. ${ }^{83}$ Thus, he could not pass judgment against his inner conviction and should refrain from rendering a decision in such cases. However, the extent to which he could base his judgment on personal knowledge needed to be defined, in order to limit the risk of arbitrariness.

Hanafī jurists following Abū Hanīfa's teaching accepted a judgment based on a qadi's knowledge of the facts, but only if he had acquired such knowledge while in office, and only within the sphere of civil claims (h̆uqūq al- ibād which, for Hanafīs, included qadhf, which entailed penal liability). ${ }^{84}$ This means, conversely, that a qadi was forbidden to take into consideration knowledge he had acquired from social interactions occurring before he took office. Al-Shaybānī (d. 189/805) was originally hostile to any use of a qadi's knowledge, whatever the type of case. ${ }^{85} \mathrm{He}$ apparently changed his mind, and, like Abū Yūsuf (d. 182/798), came to assume a qadi could take into consideration knowledge he had acquired before taking office ${ }^{86}$ Hanafĩ Iraqi jurists even gave a territorial dimension to this issue. Al-Khașșāf discusses the situation in which a qadi, while traveling outside his district, was approached by a man who wished to appoint an agent (wakil) for the purpose of suing someone in the qadi's district. Once back in his hometown, could the qadi validate the wakill's power of attorney? According to Abū Hanīfa's doctrine, al-Khașșāf answers, this is impossible because the qadi would rely on his personal knowledge and not on legal evidence. The wakil must therefore prove the validity of his appointment by producing two witnesses. Abū Yūsuf and al-Shaybānī, however, allowed the qadi to validate the power of attorney without further evidence. ${ }^{87}$

Shāfi 'i jurists also accepted such a judgment within the sphere of civil claims, although contrary opinions were attributed to al-Shāfi '⿳亠 himself. ${ }^{88}$ Conversely, Mālikīs rejected any judgment based on a qadi's knowledge, regardless of the legal subject matter. Qadis can only rely on what they know about witnesses: they should not accept the testimony of a witness

\footnotetext{
${ }^{82}$ Wakī‘, Akhbār al-quḍāt, II, 79.

${ }^{83}$ Ibn al-Qāṣṣ, Adab al-qāộ̄, 39.

${ }^{84}$ See Tillier, Les cadis d'Iraq, 415, footnote 192.

${ }^{85}$ Ibn Hazm, Muhallā, IX, 427.

${ }^{86}$ Al-Jașșāṣ, in Khașṣāf, Adab al-qạ̣̄̄, 119-21; Ṭahāwī, Mukhtaṣar, 332; Ṭaḥāwī and Jașṣāṣ, Mukhtaṣar ikhtilāf al- 'ulamā', III, 369.

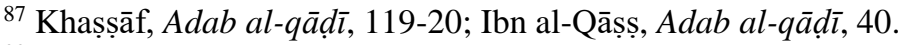

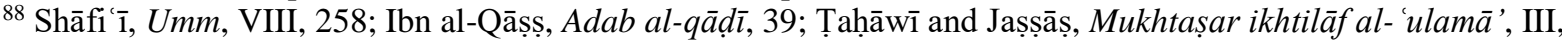
370 .
} 
whom they know is not honorable; likewise, they should not reject a witness knowing that his testimony is truthful. ${ }^{89}$

Imami jurists, from the fourth/tenth century onward, go even further, by bringing the issue of a qadi's personal knowledge into the space of the courtroom. According to al-Ṭūsī (d. 459 or 460/1066-7), hearing a defendant's confession is not enough to condemn him, for the qadi would be passing judgment based on his personal knowledge. The qadi should therefore employ witnesses who will testify that they heard the confession, which will allow him to pronounce his judgment on the basis of testimonial evidence (bayyina), rather than his knowledge of the confession. ${ }^{90}$ The only doctrine contrasting with this semi-consensus comes from the Zāhirī Ibn Hazm (d. 456/1064) in the fifth/eleventh century. In his view, a qadi's knowledge is the best evidence whatever the case. ${ }^{91}$

According to Iraqi jurists, especially Hanafīs, the impact of a qadi’s social connections on his legal practice was partly solved by drawing a distinction between the man and his official responsibilities. There should be a separation between what a qadi knew as a judge, and what he knew as a private person. With the exception of Ibn Abī Laylā's doctrine, strictly distinguishing between what the qadi learnt in court and what he learnt outside, ${ }^{92}$ the separation between a man and his function was, however, never systematically defined. Hanafis primarily developed geographical and temporal boundaries: a qadi had not always held judicial responsibilities, nor did he exercise them everywhere. Within his district and while in office, however, there was no place for the man: a qadi needed to dedicate himself, first and foremost, to his official duties.

\section{CONCLUSION}

Their position as the sole judges in their districts put early Abbasid qadis in a paradoxical situation. Inasmuch as they represented the main intermediary between the government and local populations, they had to know the latter to administer their assets and dispense justice properly. However, this very knowledge, gained through personal social experience, was likely to influence their practices and lead to bias, and therefore arbitrary decisions. A qadi could neither renounce all kinds of social interactions, nor ignore tribal links. In fact, biographical sources suggest that their social circles sometimes got the upper hand over them at the expense of justice. It remains difficult to estimate the importance of this phenomenon, as sources mainly offer models and counter-models of behavior. The danger of bias from a qadi's excessive involvement in his social environment, however, was high enough to justify legal rulings. A qadi had to stand above the fray, and limit his personal interactions with litigants. He also had to make limited use of any knowledge acquired outside the courtroom. In some provinces, such as Egypt, the growing recruitment of foreign qadis reduced society's influence on their practices, but increased that of small groups of professional witnesses. We should nevertheless assume that the proliferation of lesser courts, from the third/ninth century onward, ${ }^{93}$ often

\footnotetext{
${ }^{89}$ Ṭahāwī and Jașșāṣ, Mukhtașar ikhtilāf al- 'ulamā', III, 370; Ibn al-Qāṣṣ, Adab al-qāộ̄, 39; Ibn 'Abd al-Rafī', Mu ìn al-hukkām, II, 652.

${ }^{90}$ Ṭūsī, Mabsūt, VIII, 91.

${ }^{91}$ Ibn Hazm, Muhallā, IX, 426.

${ }^{92}$ Ibn al-Qāșș, Adab al-qạ̄̂̀, 39.

${ }^{93}$ These lesser courts, held by deputy qadis, developed in secondary towns that were not judicial centers during the previous century; Tillier, Les cadis d'Iraq, 320-323.
} 
helped maintain local recruitments in localities distant from provincial capitals, and that the influence of qadis' environment was unlikely to have disappeared.

\section{REFERENCES}

\section{Primary sources}

Ibn 'Abd al-Rafì', Mu ìn al-ḥukkām 'alā l-qaḍ̄yā wa-l-aḥkām, ed. by Muhammad Qāsim b. 'Iyāẹ, Tunis: Dār al-Gharb al-Islāmī, 2011, 2 volumes

Ibn Abī l-Wafā' al-Qurashī, al-Jawāhir al-muḍiyya fì țabaqāt al-hanafiyya, Hyderabad: Dā' irat al-Ma ārif al-'Uthmāniyya, n.d., 2 volumes

Ibn Ḥajar al- 'Asqalānī, Raf' al-iṣr 'an quḍāt Miṣr, ed. by 'Alī Muḥammad 'Umar, Cairo: Maktabat al-Khānj̄̄, 1998; French translation by Mathieu Tillier, Vies des cadis de Miṣr (257/851-366/976): Extrait du Raf' al-iṣr 'an quḍāt Miṣr d'Ibn Hağar al- 'Asqalān̄̄, Cairo: Institut Français d'Archéologie Orientale, 2002

Ibn Ḥazm, Jamharat ansāb al- 'arab, Beirut: Dār al-Kutub al- 'Ilmiyya, 2003

Ibn Ḥazm, al-Muhallā, Cairo: Idārat al-Ṭibā'a al-Munīriyya, 1352 H., 11 volumes

Ibn al-Jawzī, al-Muntazam fì tawārīkh al-mulūk wa-l-umam, ed. by Suhayl Zakkār, Beirut: Dār al-Fikr, 1995, 13 volumes

Ibn Khallikān, Wafayāt al-a 'yān wa-anbāa' abnā' al-zamān, ed. by Iḥsān 'Abbās, Beirut: Dār Șādir, 1994, 8 volumes

Ibn al-Qāṣṣ, Adab al-qạ̄̂̉, ed. by Aḥmad Farīd al-Mazīdī, Beirut: Dār al-Kutub al- 'Ilmiyya, 2007

Ibn Qutayba, 'Uyūn al-akhbār, Cairo: Dār al-Kutub al-Mișriyya, 1996, 4 volumes

Ibn Qutayba, al-Ma 'ārif, ed. by Tharwat 'Ukāsha, Cairo: Dār al-Ma 'ārif, 1969

Ibn Sa d, al-Tabaqāt al-kubrāa, Beirut: Dār Șādir, 1968, 8 volumes

Ibn Ṭayfūr, Kitāb Baġdād, ed. by Muḥammad Zāhid b. al-Ḥasan al-Kawtharī, Cairo: Maktab Nashr al-Thaqāfa al-Islāmiyya, 1949

Al-Ișfahānī, Kitāb al-Aghān̄̄, Cairo: Dār al-Kutub al-Mișriyya, 1927-61, 24 volumes

Al-Jāhịiz, Kitāb al-Hayawān, ed. by 'Abd al-Salām Muḥammad Hārūn, Cairo: Muștafāa alBābī al-Ḥalabī, 1965, 8 volumes

Al-Khaș̣̦āf, Kitāb Adab al-qạ̣̄̄, ed. by Farḥāt Ziyāda, Cairo: The American University in Cairo Press, 1978

Al-Khaṭīb al-Baghdādī, Ta 'rīkh Madīnat al-Salām, ed. by Bashshār 'Awwād Ma rūf, Beirut: Dār al-Gharb al-Islāmī, 2001, 17 volumes

Al-Kindī, Akhbār quḍāt Miṣr, in: R. Guest (ed.), The Governors and Judges of Egypt, Leiden: Brill, 1912

Al-Mas' ūdī, Murūj al-dhahab, ed. by Charles Pellat, Beirut: Publications de l'Université Libanaise, 1974, 5 volumes

Al-Qāộ̄ 'Iyāọ, Tartīb al-madārik wa-taqrīb al-masālik li-ma 'rifat a 'lām madhhab Mālik, ed. by 'Abd al-Qādir al-Ṣaḥrāwī, Rabat, 1982, 8 volumes

Al-Qālī, al-Amālī, Beirut: Dār al-Kutub al- 'Ilmiyya, n.d., 2 volumes

Al-Sam ānī, al-Ansāab, ed. by 'Abdallāh 'Umar al-Bārūdī, Beirut: Dār al-Janān, 1988, 5 volumes 
Al-Shāfi '̄ , al-Umm, ed. by Rif' at Fawzī 'Abd al-Muțțalib, al-Manșūra: Dār al-Wafă', 2001, 11 volumes

Al-Țabarī, Ta'rīkh al-rusul wa-l-mulūk, ed. by M.J. de Goeje, Leiden: E.J. Brill, 1885-1889, 16 volumes

Al-Ṭaḥāwī, Mukhtașar al-Ṭaḥāwī, ed. by Abū l-Wafā' al-Afghānī, Hyderabad: Lajnat Iḥyā al-Ma'ārif al-Nu'māniyya, n.d

Al-Ṭahāāī and al-Jașșāṣ, Mukhtașar ikhtilāf al- 'ulamā', ed. by 'Abdallāh Nadhīr Aḥmad, Beirut: Dār al-Bashā’ ir al-Islāmiyya, 1995, 5 volumes

Al-Tanūkhī, Nishwār al-muhāạara wa-akhbār al-mudhākara, ed. by 'Abbūd al-Shāljī, 1971-1973, 8 volumes

Al-Ṭ̂̄sì, al-Mabsūt fì fiqh al-imāmiyya, Beirut: Dār al-Kitāb al-Islāmī, 1992, 8 volumes

Wak̄ì', Akhbār al-quḍāt, ed. by 'Abd al-'Azīz Mușțafā al-Marāghī, Cairo: Maṭba at alSa 'àda, 1947-1950, 3 volumes

\section{Secondary sources}

Hammāda, M. Māhir, al-Wathā'iq al-siyāsiyya wa-l-idāriyya al- 'à 'ida li-l- 'asr al- 'abbāsī al-awwal. Dirāsa wa-nuṣūṣ, Beirut: Mu'assasat al-Risāla, 1979

Levi della Vida, G., Numayr, in: Encyclopaedia of Islam, Second Edition, 13 vols., Leiden: Brill, 1954-2005, VIII, 120

Sourdel, Dominique, Le vizirat 'abbāside de 749 à 936, Damascus: Institut français de Damas, 1959-1960

Schmucker, W., Yaḥyā b. Ādām, in: Encyclopaedia of Islam, Second Edition, 13 vols., Leiden: Brill, 1954-2005, XI, 244

Stern, S.M., Abān b. 'Abd al-Ḥamīd, in: Encyclopaedia of Islam, Second Edition, 13 vols., Leiden: Brill, 1954-2005, I, 2

Tillier, Mathieu, La société abbasside au miroir du tribunal. Égalité juridique et hiérarchie sociale, in: Annales Islamologiques, 42 (2008), 157-186

Tillier, Mathieu, Les cadis d'Iraq et l'État abbasside (132/750-334/945), Damascus: Presses de l'Ifpo, 2009

Tillier, Mathieu, L'identification en justice à l'époque abbasside, in: Revue des Mondes Musulmans et de la Méditerranée, 127 (2010), 97-112

Tillier, Mathieu, Les "premiers" cadis de Fusțāṭ et les dynamiques régionales de l'innovation judiciaire (750-833), in: Annales Islamologiques, 45 (2011), 214-242

Tillier, Mathieu, The Qāḍ̂̀s of Fusțâț-Miṣr under the Țūlūnids and the Ikhshīdids: The Judiciary and Egyptian Autonomy, in: Journal of the American Oriental Society, 131 (2011), 207-222

Tillier, Mathieu, Legal Knowledge and Local Practices under the Early 'Abbāsids, in: Philip Wood (ed.), History and Identity in the Eastern Mediterranean, 500-1000, New York: Oxford University Press, 2013, 187-204

Tillier, Mathieu, Judicial Authority and Qāḍ̄̄s' Autonomy under the Abbasids, in: al-Masāq, 26 (2014), 119-131

Tillier, Mathieu, The $Q \bar{a} d \bar{l}$ before the Judge: The Social Use of Eschatology in Muslim Courts, in: S.E. Holtz and A. Mermelstein (eds.), The Divine Courtroom in Comparative Perspective, Leiden: Brill, 2014, 260-275 
Tillier, Mathieu, L'invention du cadi. La justice des musulmans, des juifs et des chrétiens aux premiers siècles de l'Islam, Paris: Publications de la Sorbonne, 2017

Tyan, Émile, Histoire de l'organisation judiciaire en pays d'Islam, Leiden: Brill, 1960 